\title{
Theorising Noncitizenship: Concepts, Debates and Challenges
}

\author{
Katherine Tonkiss and Tendayi Bloom
}

Existing political theory, particularly that which deals with justice and/or rights, has long assumed citizenship as a core concept. Noncitizenship, if it is considered at all, is generally defined merely as the negation or deprivation of citizenship. As such, it is difficult to examine successfully the status of noncitizens, obligations towards them, and the nature of their role in political systems. This article addresses this critical gap by defining the theoretical problem that noncitizenship presents and demonstrating why it is an urgent concern. It surveys the contributions to the special issue for which the article is an introduction, drawing on cross-cutting themes and debates to highlight the importance of theorising noncitizenship due to both the problematic gap that exists in the theoretical literature, and the real world problems created as a result of noncitizenship which are not currently successfully addressed. Finally, the article discusses key future directions for the theorisation of noncitizenship.

Citizenship, human rights, noncitizenship, migration, political theory

\section{Introduction $\mathrm{i}$}

'Noncitizenship' is a surprisingly elusive term. While it might simple be defined as the absence of citizenship, such a definition fails to capture the complexities of practices and constructions of noncitizenship, many of which challenge traditional understandings of which it means to be included within a political community or society. Emerging sociological and cultural studies have begun to embrace the challenge of understanding what it is to be a noncitizen and the role of noncitizenship in contemporary societies as a topic in itself, not contingent on citizenship (e.g. Goldring and Landolt 2013; Nair 2012; Rigby and Schlembach 2013; Sigona 2015); however, this development has not been mirrored in political theory. As a result, normative theorising - and particularly that which is concerned with justice and rights - tends to be dominated by a) the core concept of citizenship, and b) a definition of noncitizenship as simply the negation of citizenship.

This special issue, in response to this gap, explores how liberal political theory can begin to address directly the question of noncitizenship. Bringing together scholars from legal, theoretical, sociological and applied perspectives, the special issue considers the theoretical problem that noncitizenship presents and how this problem can begin to be addressed with reference to how noncitizenship is conceptualised and the lived experience of noncitizenship. how noncitizenship is best conceptualised, its relationship with citizenship, the rights of noncitizens and the lived experience of noncitizenship.In this introductory paper, we present an examination of the absence of a detailed and accurate conceptualisation of noncitizenship within political theory and the kinds of 
questions which must be addressed to build the noncitizen into normative theorising effectively, and ways in which these questions might be successfully addressed. We advance a claim for a more sophisticated approach to the theorisation of noncitizenship and through our presentation of the papers which comprise the special issue, offer an original and interdisciplinary perspective on the relationship between membership and rights in contemporary societies.

The paper is structured as follows. After first locating the noncitizen in current literatures on citizenship, justice and rights, we highlight the problems inherent in treating noncitizenship as merely the negation of citizenship and the critical omissions from scholarly work that this has driven. We then utilise insights drawn from the papers featured in the special issue to set out the value of recognising a richer definition of noncitizenship within liberal political theory, before finally setting out an agenda for future work on the theorisation of noncitizenship, one which can also drive the inclusion of noncitizenship in policy considerations. In particular, we advocate a normative theoretical approach which embraces rich real world studies of the evolving nature of noncitizenship and its multiple forms in different geographical regions, as well as its intersections with cross-cutting social divisions such as gender and race.

\section{The Citizen-Noncitizen Binary}

It is trivial, from an etymological perspective, to state that citizenship and noncitizenship are related concepts. And indeed, we do not deny that they are interrelated. It is our argument in this section, however, that the relationship between the two concepts is far more complex than political theory has tended to presume. Primarily, we reject the idea that noncitizenship needs to be derivative, theoretically, from citizenship, instead viewing them both as foundational concepts.

Scholars typically draw attention to three interrelated attributes of citizenship (Bloemraad et al. 2008; Cohen 1999). The first aspect of this is legal, that citizenship is a status which grants rights to the holder while expecting her to meet obligations to the State in return. According to this dimension, citizenship status confers the 'right to have rights' in Hannah Arendt's famous words (1968), with the status of citizenship acting as a gateway to a range of civil, political and social rights (Marshall 1992). The second attribute is political - that citizenship denotes active participation in the governance of the State in which the individual holds the status. This is the classical Greek definition of citizenship, and indeed also reflects a republican notion of political membership in contrast to being a subject of a sovereign (e.g. Dagger 1997). The third is identity-based - that citizenship confers on an individual the identity of membership in the citizenry (Joppke 2007).

While the Western conceptualisation of citizenship was constructed prior to the emergence of the nation-state system, with traditions of citizenship rooted in Ancient Greek and Roman societies, in the modern world the two have become so deeply linked that 'national citizenship', as citizenship of the nation-state, is a virtually hegemonic 
idea, challenged only be emerging transnational citizenship regimes such as the European Union (Habermas 1995; Isin and Turner 2007). However, scholars are increasingly questioning the national citizenship compound given that a) international migration has increased and intensified, and b) an international human rights regime has emerged (Abizadeh 2002; Habermas 1998; Soysal 1994). These dynamics have meant that, while still a very significant factor, membership of a national group is playing a less pronounced role than it once did in determining place of residence and access to core rights. As a result, these developments have altered the ability of a State to control membership of its community through the projection of membership criteria based on national membership (Kofman 2006; Joppke 2007). The contemporary politics of migration control are shaped by this erosion of nation-state control and national identity in an increasingly globalised and interconnected world.

This questioning of the national model of citizenship has led to something of a decentring of traditional theories of citizenship. The Marshallian vision of citizenship has come under increasing critique as a result of the decreasing relevance of homogeneous national identity to citizenship (cf. Bloemraad et al. 2008; Isin and Turner 2007; Turner 2001). Citizenships are viewed as co-existing in multiple forms and at multiple levels of political integration, and as intersecting with different forms of social division such as gender, class and race (Lister 2007; Yuval-Davis 2007). As a result, citizenship is recognised as a practice (or an 'act') in addition to a status (Isin 2008), and citizenships beyond the State are increasingly explored as a result of the apparent paradox between nation-state citizenship and the more post-national, transnational and cosmopolitan realities of international migration practices and multi-national and diasporic communities (Kaldor 2003; Soysal 1994; Müller 2007; Tonkiss 2013).

These developments have led to the emergence of works of normative political theory which challenge traditional understandings of the scope of justice - or to what extent and to whom justice and/or rights should apply. In response to John Rawls' presumption of the limits of the State as the limits of justice, where it is only relationships between co-citizens, or indeed heads of households, of the same State which are relevant in considerations of justice $(1971 ; 1999)$, theorists have sought to explore the extension of Rawlsian principles of justice beyond the State, and thus to extend the argument beyond co-citizens (Beitz 1979; Pogge 1989; 2002), while others have proposed more radical options such as the construction of global institutional and a global citizenship regime (Cabrera 2004; 2010; Held 2004). Still others have argued that the rights typically associated with citizenship apply more widely than this specific category (Weissbrodt 2009) and have explored how the rights of citizenship could be extended beyond traditional models, offering justifications for liberal migration rights and more open access to citizenship for those born outside of the State (Benhabib 2004; Carens 2013). This shift includes, crucially, the development of critiques of the persistence of citizenship based on 'birthright', challenging dominant models (Shachar 2009; Nyers 2006). 
These theorists seem to be primarily concerned with noncitizenship, inasmuch as noncitizenship is defined as the absence of citizenship. In a more mobile and interconnected world where citizenship is increasingly deterritorialised and memberships recognised as multiple and overlapping, these theorists ask: how should we conceive of the rights of those without access to citizenship, and how should citizenship be transformed as a result? Their answers support the extension of citizenship beyond its traditional limits, and propose more inclusive and fluid forms of citizenship; or at the other extreme, lament the challenges of increasing transnationalism for constructing the robust binding sentiment of national identity which, it is suggested by these critics, is necessary for a robust and active citizenship to emerge (Miller 2000; Tamir 1993; Walzer 1983).

While it is vital to critique to existing limits of citizenship, in these approaches it seems that the theorisation of justice and rights affecting noncitizens is only thought about in relation to the conceptualisation of citizenship and its relationship with justice and rights, a problem which is also compounded by the privileged position of political theorists who themselves hold citizenship of affluent States (noted by Cole 2014). Noncitizenship is defined as an absence, which is logical, but we would contend that this is too simplistic and that noncitizenship is a membership category in its own right. The decentring of citizenship has revealed its contingent and constructed nature, as well as its intersections with other social divisions, and has led to much critique of the status quo. Yet this decentring has not been extended to noncitizenship, and this is problematic. Moreover, noncitizenship should not be seen as a migratory category. Many instances of noncitizenship arise from migration, as is reflected in much of the literature pertaining to noncitizenship, and indeed the formal recognition of noncitizenship as a positive status beyond the simple absence of citizenship, which is for the most part tied to a form of migration (giving rise to statuses such as: economic migrant, asylum seeker, undocumented migrant and so forth). Yet in fact the category is wider, including persons who participate in a noncitizenship relation in a State without crossing international borders. Indeed, this is brought out in some of the contributions to this volume (discussed below).

Noncitizens also have diverse experiences and belongings, which are shaped by intersections with other social divisions. A definition of noncitizenship as the negation of citizenship overlooks these critical dynamics. Exploring these in detail before reconstructing noncitizenship presents the potential for a conceptualisation of noncitizenship as a category of membership which is capable of shaping theorising about membership and rights in contemporary societies. In other words, before we can effectively theorise how justice and rights should be extended to noncitizens, we need a full, robust and accurate conceptualisation of noncitizenship.

Some traditional ways of understanding noncitizenship, in the form of 'denizen', 'resident' and 'dhimmi' are noteworthy for their use in imagining statuses beyond that of citizen. However, these do not quite achieve what is intended by the term 
noncitizenship in this paper. Denizen, from the medieval French for 'inhabitant', was a legal status something like 'resident' in medieval Britain.ii Its recent uses have been more problematic, when members of certain groups were considered ineligible for full citizenship, and so were given the status of denizen. As such, residency and denizenship can be seen as an intermediary or stand-in status where there should properly be citizenship, rather than a way of understanding noncitizenship. While the experience of persons given this sort of status may be a form of noncitizenship, such a status cannot encapsulate the noncitizenship described here. Dhimmi, though etymologically different (deriving from the status of conquered peoples in relation to their conquerors), has had similar uses to denizen in Islamic political theory and practice (e.g. Shoukri 2011 from p.58) and as such, it also does not provide the notion of noncitizenship being sought here.

The task of constructing a full and accurate conceptualisation of noncitizenship is critically important for two reasons. Firstly, the lack of attention to, and inadequate conceptualisation of, noncitizenship has given rise to a problematic gap in liberal political theory. It is not possible to develop comprehensive political theory when the concerns of a significant proportion of persons are excluded from these considerations (e.g. discussed in Cole 2000). We argue that theorists have been unable so far to respond to this difficulty because the theoretical tools available for talking about membership and rights are inherently dependent on citizenship, and our ability to appreciate what the paradox between national citizenship regimes and globalised memberships should mean for the scope of rights and justice is limited by a reliance on the conceptual boundaries of citizenship. This lack of appropriate means of analysis is evident in the traditional hyphenated terminology of 'non-citizenship', a hyphenation which we reject in this special issue.

Secondly, the weak conceptualisation of noncitizenship means that contemporary political theories are less able to speak to the kinds of real world issues that noncitizens face. In particular, those with non-national memberships, persons in diasporas, temporary workers, those seeking protection, and members of nomadic groups will remain beyond the scope of the work of political theorists unless they are to work with a more rigorous understanding of noncitizenship beyond its definition as the negation of citizenship rights. In many cases, taking a binary approach to the definition of noncitizenship is problematic in what it omits. Theorists focus on the absence of the legal status of citizenship and its attendant rights without considering the highly differentiated experiences of noncitizenship and the complex ways in which the three dimensions of citizenship (legal, political and identity) interact to construct the exclusion of different categories of noncitizens. Work is needed to examine the relationship between rights and belonging when there are multiple sources of identity and membership (Quiroz Becerra 2014; Tonkiss 2013; Yuval-Davis 2007), and multiple forms of political participation unrelated to citizenship (Nair 2012; Rigby and Schlembach 2013; Sigona 2015). 
The kinds of real world challenges presented by noncitizenship which existing political theory struggles to address are seen most keenly in the case of statelessness. The literature on statelessness is still underdeveloped; however, some writers offer theorisations of the status nd lack of status of statelessness, and relate this theorisation to real world problems and modes of change. The focus on citizenship as the core form of relationship with the State means that, as Arendt points out, the removal of citizenship can apparently legitimise the exclusion from basic rights of members of certain groups (Arendt 1968, 167; see also Sassen 1999). Indeed, in the case of stateless persons, the lack of any State as a default for rights protection makes clear the danger of noncitizenship seen only as the negation of citizenship at its most extreme (CaballeroAnthony et al 2013,161). The international legal and theoretical frameworks are not yet able to ensure the rights of these presons, who are noncitizens everywhere (Batchelor 1998; Blitz 2009). We argue that this is entrenched by the upholding of citizenship as the only relevant core relationship with a State, even when international agreements allow otherwise (Weissbrodt 2009).

Indeed, the colloquial treatment of stateless persons and irregular migrants is also particularly telling, as their relationship with the State can often be defined according to a lack. Consider, for example, persons referred to as 'sin papeles' ('without papers') in Spain, and as 'sans papiers' ('without papers') in France, as well as the 'bidoon' (short for 'bidoon jinsiya', or 'without nationality') in the States of the Arab Gulf. This colloquial way of referring to persons solely by their lack of a formal relationship with the State has the effect of reinforcing the idea that there is no relationship and enabling their exclusion from even core rights protections. Yet, as the papers in this volume attest, this is not an accurate picture. This is seen most clearly when noncitizenship is theorised as a positive relationship with a State, as is presented here.

It is our purpose in this special issue to begin the process of building the notion of noncitizenship as a distinct perspective into political theory, by bringing together an interdisciplinary collection of papers offering insights into the theoretical problem that noncitizenship presents and how to develop a more robust conceptualisation of this term. how to develop a robust conceptualisation of noncitizenship. As noted, we use the term 'noncitizenship' rather than 'non-citizenship' in order to move beyond the binary definition described, embracing a diversity of experiences while drawing out crosscutting practices and exclusions affecting these multiple forms of noncitizenships. We will shortly introduce this conceptualisation of noncitizenship as a basis for liberal political theory with reference to the contributions of the special issue. Before we do so, however, we briefly survey the insights offered by some recent interventions on the subject and their relationship with the ideas presented in this volume.

\section{Emerging Noncitizenship Studies}

At the time of writing, two other important volumes about noncitizenship have recently been published, contributing to serious and developed study in this area. This current 
volume must be seen as taking a crucial next step. January 2014 saw the publication, in the Critical Review of International Social and Political Philosophy (CRISPP), of a Special Issue under the title Domination, Migration and Non-Citizens, edited by Iseult Honahan and Marit Hovdal-Moan. Then, months later, in September 2014, another Special Issue appeared, this time in Politics and Society, with the title The Rights of Noncitizens, edited by David Plotke. The close timing of the publication of these three works demonstrates the urgent need to address these issues. These volumes are critically important for the emergence of a rich literature on noncitizenship, and while the papers presented in the current volume take a distinctly different perspective, they do build on these recent studies in key ways.

Honohan and Hovdal-Moan's Special Issue focuses on the notion of 'domination' in discussion of migration and citizenship (2014), defining domination 'in terms of the subjection to the threat of arbitrary interference' (Honohan and Hovdal-Moan 2014, 2). The (usually republican) domination perspective is an important one. Yet the writers in the CRISPP collection analyse noncitizenship primarily as a result of migration. They explore the domination of migrants and noncitizens almost interchangeably (some refer to denizenship to describe territorially present noncitizens - e.g. Benton 2014). While their presentation of vulnerability in the form of domination is important and interesting, particularly in terms of the emphasis on the arbitrary domination of those with different statuses (e.g. Hovdal-Moan 2014), we worry that it may also reinforce the idea that there are easily distinguishable mutually exclusive categories of citizens and noncitizens. The insertion of the alternative category of denizen could, prima facie, allow for a more fluid understanding of memberships. However, as argued above, it instead acts as an interim between noncitizenship (as an external category) and citizenship and, as such, reinforces this binary distinction.

Christopher Bertram (2014), in this important domination-focused special issue, analyses what he calls 'perimeter fence' and 'social boundary' forms of exclusion, arguing that both carry problems - and this is something that our volume builds upon, though with an analysis of the relationship between the State and those engaging with each of the barriers that he describes. Indeed, this relationship with the State is a crucial aspect of understanding the situation for noncitizens. This is emphasised by Sarah Fine who refers to Hannah Arendt's comment that man 'can lose all so-called Rights of Man without losing his essential quality as man, his human dignity' (Arendt 1951, 297, quoted in Fine 2014, p.14). She notes how, without citizenship, in the world of States, a man can be denied those human rights that are in fact tied to citizenship. Echoing (but not referring to) Bentham's suggestion that the notion of human rights is 'nonsense on stilts' (Bentham 1843) in the 'absence of a state willing (or another agent able) to protect and enforce them' (Fine 2014,14). This is particularly interesting when seen in contrast to David Owen's contribution to the same issue (Owen 2014). Owen argues that a migration status may involve an arbitrary exercise of power over the statusbearer; and that it may arise out of an arbitrary exercise of power over that person 
(Owen 2014, 91). He argues that a legitimate migration status must not impose domination in either of these forms over those subject to that State's rule.

The emphasis throughout the Honohan and Hovdal-Moan volume is on access to citizenship and this precludes the development of a solid notion of noncitizenship. The analysis of domination in cases of migration and noncitizenship is useful and important. However, from our perspective, this leaves out a key means of resolving the difficulties raised. Several of the problematics presented in articles in the Honohan and HovdalMoan volume could be usefully addressed through a recognition of a notion of noncitizenship, with an understanding of noncitizenship as a particular sort of relationship with a State, giving rise to the potential for particular forms of domination - forms which the authors instead address using various migratory statuses.

The crucial matter of The Rights of Noncitizens examined in the September Special Issue edited by Plotke reaffirms the importance of this topic. The papers raise again the problem that noncitizens may be excluded from rights regimes often intended primarily for citizens. The examples presented in the papers in the Politics and Society volume join us in challenging the idea that there is a clear divide between citizenship and noncitizenship and as such they provide critically important reading within this emerging discipline. However, the solutions offered tend to relate back to citizenship, and to an understanding of citizenship still as the foundational concept. We argue that challenging the foundationalism of citizenship is necessary in order to conceptualise a situation in which noncitizens have access to rights, not as a magnanimous gesture and not through the issuing of citizenship, but instead through an appreciation of the rights of noncitizens themselves.

For example, Els de Graauw (2014) reinforces Pogge's notion of a form of variegated membership structure (e.g. see Pogge 1999) by locating cities as sites of belonging. Indeed, if persons can effectively be citizens of cities, without having that status on the national level, this enables a more complex understanding of citizenship. However, this notion of city membership continues to function on the idea that there are citizens, who are insiders, and noncitizens who are outsiders, though at different levels. The border between citizen and noncitizen is, also challenged by others in the Plotke volume, looking at how noncitizen engagement in communal activities implies a communal membership without official status (Quiroz Becerra 2014); at the implications of migration in situations where the State is not acting as the focal point for legal rights so that communal memberships in fact become more important (Landau 2014); where intertwined histories of colonialism and conflict mean that memberships and State obligations are more complex than evidenced solely in citizenship (Smith 2014); or when a shared victimhood among citizens and noncitizens creates a membership even when it is not officially recognised (Délano and Nienass 2014).

The papers in the Politics and Society collection aim to 'address difficult questions about how the boundaries of citizenship are drawn (and should be drawn) in countries with 
large numbers of noncitizen residents' (Plotke 2014, p.289). The current volume goes one step further. It asks whether it is helpful to focus on boundary-drawing at all, and advocates instead starting with noncitizenship as itself a foundational concept, and indeed itself representative of a special relationship with the State. The aim, then, for us, is not to 'reconcile citizenship, membership, and presence in decent political regimes' (Plotke 2014, 290), so much as to revisit the case and to note that noncitizens have rights in virtue of their relationship with a State.

Plotke warns against an approach that would be directed at toppling citizenship (Plotke 2014,291 ) and this is not the aim here either. However, a proper understanding of noncitizenship will certainly lead to a better understanding of the practice of citizenship in contemporary societies and, as such, will contribute to a steadying also of the notion of citizenship.

\section{Interdisciplinary Approaches to Theorising Noncitizenship}

The papers in this volume do two things. First, they present why it is crucial to develop a way to theorise noncitizenship without assuming citizenship as a foundational concept. Second, they offer their own distinct perspectives on how to do so. They argue that citizenship should not be seen as the only foundational concept, and that noncitizenship should not only be seen as an absence of a lack, with the rights of noncitizens as an add-on or an approximation to something relating to citizenship. In turn, this will help theorists and policy-makers respond to changing landscapes, in which it is becoming increasingly important to address directly the needs of noncitizens, and in which new frameworks will be needed in order to acknowledge and actualise them.

The project of finding a new way to theorise noncitizenship needs to be multidisciplinary, interweaving theory and practice in new ways. Luin Goldring and Patricia Landolt (this volume) show how noncitizenship is heterogeneous and complex in ways which are overlooked by the definition of noncitizenship as mere negation and by the ways in which noncitizens have been 'siloed' into specific categories for the purposes of academic study. They argue that noncitizenship is socially constituted by the ways in which individuals and institutions navigate laws, policies and procedures in multiple settings, by the ways in which noncitizenship is discursively framed in those settings, and by both noncitizen agency and the actions of individuals and institutions who may help or hinder access to rights. As a result, the rights of noncitizens may be realised differently in different social contexts, something which the authors demonstrate through the presentation of four diverse cases which show how noncitizenship is conditional and crucially tied to agency, an analysis that is supported by the cases provided by Heather Johnson (this volume) and Shanthi Robertson (again, this volume). As such, the It is made up of legal categorisations, social relations, and access to resources and services. Moreover, this very complexity they highlight 
becomesis itself crucial for understanding the societies in which individuals come to hold noncitizenship status, and the relations between citizenship and residency.

-These themes are then taken up by David Weissbrodt and Michael Divine (also this volume) who argue, from a legal standpoint, that a noncitizen's legal status may well in practice preclude him or her from access even to those human rights protections to which he or she is entitled by international agreement. Once again, the nature of noncitizenship is contingent on the nature of the social context in which it is enacted. As such, the construction of noncitizenship as a negation of citizenship introduces more privation than is apparent, for example, from legal systems. Together, Goldring and Landolt Weissbrodt and Divine set the stage for a new way to theorise noncitizenship as a situation of conditionality and continfency, of vulnerability, but also one which helps us to understand the meanings of membership, rights and the State.

Goldring and Landolt demonstrate how the analysis of noncitizenship can itself help us to understand citizenship and the State. Through an examination of the experience of noncitizenship in four Canada-based case studies, they provide a way to deconstruct the complex social organisation of noncitizenship as a status that is conditional and erucially tied to agency, an analysis that is supported by the cases provided by Heather Johnson (this volume) and Shanthi Robertson (again, this volume). What comes out of this is a noncitizenship that is composed of complex and dynamic social relations that mediate legal status. That is, noncitizenship is more than legal status, and is crucial for understanding wider social conditions, but it is also strongly tied to legal status which is relevant for reinforcing those other factors.

Similar conclusions come from a legal perspective. Weissbrodt and Divine examine how an understanding of the categories of noncitizenship can help to show how noncitizenship per se restricts persons' access to human rights. Indeed, this can be the case even when international agreements explicitly include noncitizens in the population to be protected. As they put it, 'international human rights law is built upon the foundational premise that every person, by virtue of their existence, is entitled to certain rights and protections'. Despite this, persons can be excluded from human rights protections. In order to respond to this situation, international law has created certain categories of noncitizens with explicit sets of protections. Weissbrodt and Divine identify: stateless persons, refugees and asylum seekers, noncitizen workers, victims of trafficking and children. They present a situation in which these groups are given certain specific protections, which in effect excludes again those noncitizens not able to demonstrate membership of one of these categories. This, they argue, has specific ramifications for irregular migrants, whose irregularity can often be sufficient justification for their lack of even very basic protection from discrimination and abuse. The absence of a notion of noncitizenship in international law means that it is difficult to allocate and enforce the allocation of the responsibility to protect those individuals unable to prove a particular noncitizenship status. 
Another type of entity engaged in noncitizenship construction, and whose role has been little theorised, are those in the private sector. While the migration industry is huge and growing, Tendayi Bloom (this volume) provides an analysis of privatised migration control specifically, as a crucial part of the larger industry, and deeply tied to migration facilitation. Her taxonomy of the migration control industry offers a new way of understanding the roles of non-State actors in migration control and as a result, the new modes of noncitizenship construction taking place in the private sector. Bloom presents the private sector as an often unnoticed mediator of State migration control, and in fact therefore a constructor of noncitizenship. She argues that the very involvement of the private sector in some cases creates problems for the legitimacy of noncitizen-exclusion measures and alters the noncitizen-State relationship.

Analysis of noncitizenship can sometimes imply that it is essentially tied to migration; yet, as argued above, this is inaccurate. This is demonstrated by-Kristy Belton's article (this volume) serves to demonstrate the importance of recognising the non-migrant status of many noncitizens when conceptualising noncitizenship. She describes who presents how situations of statelessness (noncitizenship everywhere) are being created in situ in the Caribbean context. Drawing from the particularities of her the-case studies of the Bahamas and the Dominican Republic, she describes, Belton argues that a system in which there is either (specifically national) citizenship or noncitizenship, persons who are excluded from citizenship are seen as without relationship of obligation with the State and put into situations of extreme vulnerability both in terms of physical protection and in terms of personal membership identity. Crucially, however, she equates this situation with one of 'immobility', and she argues that in the absence of a more complex theoretical and legal concept of noncitizenship, people can be stranded in unfavourable socioeconomic or geographic situations with a lack of personal agency. As such, Belton contributes both a crucial facet to the conceptualisation of noncitizenship as not intrinsically a matter of migration, and highlights that critical real world problems cannot be addressed without a new, more complete and accurate language of noncitizenship.

While the first four papers of this collection have focused primarily on the construction of noncitizenship by others - by the State, the society, the lawmakers, and the private sector, Paulina Tambakaki looks at the noncitizenship construction deriving from noncitizens themselves (this volume). Coming from the perspective of radical democracy theory, in which she re-examines what it is to be a democratic subject, Tambakaki introduces the idea of 'subversive politicisation' which can avoid the traditional construction of a citizen/noncitizen binary. For her, noncitizenship and citizenship must be examined together as separate but intertwined concepts. By analysing the nature of noncitizenship and how it functions within a system of what she refers to as 'citizenisation', she advocates either an expansive and inclusive understanding of citizenship or, better, a rejection of both the citizen and the noncitizen concepts all together. She argues, however, that a system based on a citizen-noncitizen binary cannot successfully characterise the political reality. 
To build upon these more general and theoretical approaches, it is useful to hone in on some theorised case studies. In particular, Shanthi Robertson (this volume) and Heather Johnson (also this volume), separately, look at the noncitizen construction of noncitizenship through case studies. Importantly, their findings both complement and challenge each other. Robertson's Australia is a context in which noncitizenship is being constructed as a state of powerlessness and in-between-ness, as has been brought out by earlier writers. However, she argues that in so doing, the Australian State constructs a new form of noncitizenship, as a temporary condition before citizenship. She shows noncitizenship as a non-status, not recognised even by noncitizens themselves as important, who instead look towards forms of formal status acquisition. Solidarity movements that exist in Australia, Robertson argues, exist as networks of co-workers, or co-ethnics, not explicitly drawing on a shared noncitizenship. As such, noncitizens themselves also construct noncitizenship, not as a status in its own right, but in opposition to the rights of citizenship as this is the framework within which they can best see a way to obtain human rights protections in their particular Australian context.

Heather Johnson's approach is the reverse. She examines precisely a noncitizen solidarity movement, this time in Austria. She argues that in the case she studies, the members of the movement mobilise around the notion of noncitizenship, sometimes referred to as 'refugees' (not necessarily in the sense of the legal definition of refugee, but to denote what we are referring to in this volume as 'noncitizens'). Linking the protest to other protests in Europe, Johnson argues that it is precisely the mobilisation of noncitizenship as a status in itself, collectively and individually vulnerable to the State, which drives the movement, as a 'self-organised struggle'. Indeed, the actors she presents argue not for the protections of citizenship, but for rights as noncitizens who may well be integrated into 'collective life', though not holding formal citizenship status and not desiring to hold it. As such, while Robertson finds that in the Australian context there is not space for solidarity on the basis of noncitizenship alone, Johnson sees a European situation in which noncitizens can mobilise on the basis of their collective vulnerability, and challenge the lines between a dichotomous understanding of membership and non-membership.

Noncitizenship is a non-derivative status, which needs to be examined as a starting point in its own right, without deference to citizenship. When this is done, it can provide a crucial foundation to an enriched understanding of rights, membership and society. It can inform analysis of citizenship and can be informed by citizenship. This volume demonstrates the need for an integrated approach, weaving law and legal studies with sociology and anthropology, and politic real with political theory, ensuring that theoretical approaches are informed by, and work on, the ground.

\section{A Future Agenda for Theorising Noncitizenship}


The contributors to this Special Issue have, then, provided a multi-disciplinary analysis of noncitizenship as it is theorised, problematized and practised. Their rich insights highlight some particularly central features which should be drawn on in theorising noncitizenship as a foundational concept in political theory. It is hoped that this can drive a new agenda in the theorisation of noncitizenship and, in turn, in developing policy which can properly ensure the protection of the rights of noncitizens.

The first key point is that noncitizenship is heterogeneous and complex. It is not a single, neat category but rather an amalgamation of different categories according to status, both official and not, and cutting across different social divisions and relationships. The second key point is that noncitizenship is constructed by multiple actors, in different places and through different modes. State actors, non-State actors and individual noncitizens themselves all play a role in constructing the noncitizenship category. Although it has not been considered in this volume, it is likely also that individual citizens play a role in constructing noncitizenship, a topic touched upon elsewhere (e.g. Tonkiss forthcoming). This characterisation of noncitizenship as heterogeneous, complex and constructed by multiple actors is critical to developing a rich and rigorous understanding of noncitizenship. Indeed, the ways in which noncitizenship is constructed and by whom, and how it intersects with other social divisions, shape the nature of the inclusions and exclusions from society which are experienced by noncitizens.

We are keenly aware that, in the space of this Special Issue, it has not been possible to consider all of the key complexities which shape noncitizenship. This includes the construction of noncitizenship in contexts beyond those geographic regions mentioned here (particularly African, Asian and Latin American contexts are missing here); as well as the ways in which noncitizenship is mediated through other social locations such as race, class, gender, sexuality and disability. A full theorisation of noncitizenship would need to embrace these additional diversities of the noncitizen experience. However, we hope that in conceptualising noncitizenship as heterogeneous and complex we have at least been able to emphasise the critical importance of these features to producing a robust theory of noncitizenship and to indicate how these other factors could be incorporated. The third key point to take away from the papers is that the relationship between noncitizenship and citizenship is also complex and multi-faceted, rather than dichotomous. The heterogeneous nature of noncitizenship means that there are many different points at which noncitizen and citizen categories intersect with diverse consequences. This supports our assertion that noncitizenship is far more than the binary opposite of citizenship but rather itself is a relationship between a noncitizen and a State in its own right, and highlights the complex, overlapping and fragmented nature of memberships in contemporary societies. The study of intersections between noncitizenship and citizenship has also been beyond the scope of the featured papers, but examining noncitizenship and citizenship at their transition points could add valuable insights to further break down the simplistic assumptions associated with the relationship between the two categories. 
The fourth and final key point from the papers is that noncitizenship is associated with vulnerability and powerlessness. This might be the vulnerability which results from a lack of basic human rights, the vulnerability of lacking permanence in the country of residence, or the vulnerability of the individual against State and non-State actors. Yet it also might lead us to examine instances challenging the vulnerability of noncitizens through counter-movements and protests (such as that seen in Johnson, this volume), which in itself suggests the value of conceptualising noncitizenship as vulnerability for speaking to real world concerns and problems. While noncitizenship is often thought of as exclusion - exclusion from the citizenry, exclusion from rights - focusing instead on the idea of vulnerability provides a way of theorising rights and justice as they affect noncitizens without recourse to the binary definition of noncitizenship which, as noted, does not reflect how noncitizenship exists in the real world.

As a result, the papers in this Special Issue have emphasised that noncitizenship is far more than a lack of citizenship status, and that in this sense it is active - an individual is a noncitizen, rather than not-a-citizen. Noncitizenship as a heterogeneous category of social membership in its own right which has a fluid and multi-faceted relationship with citizenship, and which is characterised by the experience of vulnerability, presents a useful starting point for theorising rights and justice, embracing the fractured and multiple nature of membership in contemporary societies and positioning the noncitizen in relation to justice and rights.

This paper is not intended as a cohesive theory of noncitizenship, but rather as a means to begin to address the absence of a robust conceptualisation of noncitizenship which could underpin a political theory which takes noncitizenship as a starting point, rather than assuming the centrality of citizenship. Our intention was not to present a cohesive political theory of noncitizenship, but rather to demonstrate the value of conceptualising noncitizenship as a concept in its own right. In doing so we have illustrated the central importance of an approach which embraces interdisciplinarity in order to draw on research into the real world experiences of noncitizens as well as the operation of noncitizenship through institutions in the real world, and an approach which combines rigorous theorising with rich insights from empirical research.

As a result, we are able to identify some key features of a future research agenda focused on theorising noncitizenship. This agenda has two inter-related aspects, the first of which is conceptualising noncitizenship. This collection has brought together a number of different approaches to this, and we suggest that building on these to further refine the conceptualisation, particularly with regards to the operation of noncitizenship in contexts beyond the developed world and to its experience in relation to other social divisions, is pressing. The second feature of our research agenda is the production of political theories which are grounded in noncitizenship as a foundational concept, drawing on and justifying one or more of these conceptualisations to offer new accounts of the relationship between membership, justice and rights in contemporary societies. For both of these aspects, we support an approach which combines theory 
with insights from the real world and looks towards supporting the development of policy that properly acknowledges the relationship of noncitizenship and the need for protection, as the best means for addressing both the gap in theory surrounding noncitizenship and the inability of theory, at present, to speak to the real world concerns of noncitizens.

\section{References}

Abizadeh, Arash. 2002. "Does Liberal Democracy Presuppose a Cultural Nation? Four Arguments." American Political Science Review. 96 (3): 495-509.

Arendt, Hannah. 1968. The Origins of Totalitarianism. San Diego: Harvest Harcourt.

Batchelor, Carol. 1998. "Statelessness and the Problem of Resolving Nationality Status." International Journal of Refugee Law 10 156-183.

Beitz, Charles. 1979. Political Theory and International Relations. Princeton: Princeton University Press.

Belton, Kristy. 2013. "Statelessness and Economic and Social Rights." In In The State of Economics and Social Human Rights: A Global Overview, edited by Lanse Minkler, 221247. Cambridge: Cambridge University Press.

Benhabib, Seyla. 2004. The Rights of Others: Aliens, Residents and Citizens. Cambridge: Cambridge University Press.

Bentham, Jeremy. 1843. 'Anarchical Fallacies: Being an Examination of the Declarations of Rights Issued during the French Revolution. Pp.489-543 in The Works of Jeremy Bentham volume II. Elibron Classics.

Benton, Meghan. 2014. "The Problem of Denizenship: a Non-Domination Framework." Critical Review of International Social and Political Philosophy 17(1): 49-69.

Bertram, Christopher. 2014. "Competing Methods of Territorial Control, Migration and Justice.” Critical Review of International Social and Political Philosophy 17(1): 129-143.

Blitz, Brad. 2009. Statelessness, Protection and Equality, Forced Migration Policy Briefing 3, Refugee Studies Centre, University of Oxford.

Bloemraad, Irene, Anna Korteweg, and Gökçe Yurdakul. 2008 "Citizenship and Immigration: Multiculturalism, Assimilation and Challenges to the Nation-State." Annual Review of Sociology 34: 153-179.

Cabrera, Luis. (2004) Political Theory of Global Justice. London: Routledge. 
Cabrera, Luis. (2010) The Practice of Global Citizenship. Cambridge: Cambridge University Press.

Carens, Joseph. 2013. The Ethics of Immigration Oxford: Oxford University Press.

Carens, Joseph. 1987. “Aliens and Citizens: The Case for Open Borders.” The Review of Politics 49(2): 251-273.

Cohen, Jean L. 1999. "Changing Paradigms of Citizenship and the Exclusiveness of the Demos.” International Sociology 14 (3): 245-268.

Cole, Phillip. (2014) "Beyond Reason: The Philosophy and Politics of Immigration." Critical Review of International Social and Political Philosophy 17 (5): 503-520.

Cole, Phillip. Philosophies of Exclusion. Edinburgh: Edinburgh University Press.

Dagger, Richard. 1997. Civic Virtues: Rights, Citizenship and Republican Liberalism. Oxford: Oxford University Press.

Délano, Alexandra and Benjamin Nienass. 2014. "Invisible Victims: Undocumented Migrants and the Aftermath of September 11." Politics \& Society 42(3): 399-421

Ellermann, Antje. 2014. "The Rule of Law and the Right to Stay: The Moral Claims of Undocumented Migrants." Politics \& Society 42/3.

Fine, Sarah. 2014. "Non-domination and the Ethics of Migration." Critical Review of International Social and Political Philosophy 17(1): 10-30.

Golding, Luin and Patricia Landolt. 2013. Producing and Negotiating Non-Citizenship: Precarious Legal Status in Canada. Toronto: University of Toronto Press.

de Graauw, Els. 2014. "Municipal ID Cards for Undocumented Immigrants: Local Bureaucratic Membership in a Federal System." Politics \& Society 42/3.

Habermas, Jürgen. 1995. "Citizenship and National Identity: Some Reflections on the Future of Europe." In Theorising Citizenship, edited by Ronald Beiner, 255-282. Albany: SUNY Press.

Habermas, Jürgen. 1998. The Inclusion of the Other. Cambridge: Polity.

Held, David. 2004. Global Covenant: The Social Democratic Alternative to the Washington Consensus. Cambridge: Polity.

Honohan, Iseult. 2014. "Domination and Migration: An Alternative Approach to the Legitimacy of Migration Controls." Critical Review of International Social and Political Philosophy 17(1): 31-48. 
Honohan, Iseult and Marit Hovdal-Moan. 2014. "Introduction: Domination, Migration and Non-Citizens." Critical Review of International Social and Political Philosophy 17(1): $1-9$.

Hovdal-Moan, Marit. 2014. "Unequal Residence Statuses and the Ideal of NonDomination." Critical Review of International Social and Political Philosophy 17(1): 7089.

Isin, Engin. 2008. "Theorising Acts of Citizenship.” In Acts of Citizenship, edited by Engin Isin and Greg. London: Zed.

Isin, Engin and Bryan S. Turner. 2007. "Investigating Citizenship: An Agenda for Citizenship Studies." Citizenship Studies 11 (1): 5-17.

Joppke, Christian. 2007. "Transformation of Citizenship: Status, Rights, Identity." Citizenship Studies 11 (1): 37-48.

Kofman, Eleonore. 2005. "Citizenship, Migration and the Reassertion of National Identity." Citizenship Studies 9 (5): 453-467.Landau, Loren B. 2014. "Conviviality, Rights, and Conflict in Africa's Urban Estuaries.” Politics \& Society 42 (3): 359-380.

Lister, Ruth. 2007. "Inclusive Citizenship: Realising the Potential 1." Citizenship Studies 11 (1): 49-61.

Marshall, Thomas H. 1992 [1950]. Citizenship and Social Class. London: Pluto Press.

Miller, David. 2000. Citizenship and National Identity. Cambridge: Polity.

Nair, Parvati. 2012. "The Body Politic of Dissent: The Paperless and the Indignant." Citizenship Studies 16 (5-6): 783-792.

Nash, Kate. 2009. "Between Citizenship and Human Rights.” Sociology. 43 (6): 10671083.

Nyers, Peter. 2006. "The Accidental Citizen: Acts of Sovereignty and (Un)Making Citizenship." Economy and Society 35 (1): 22-41.

Owen, David. 2014. "Republicanism and the Constitution of Migrant Statuses." Critical Review of International Social and Political Philosophy 17(1): 90-110.

Plotke, David. 2014. “The Rights of Noncitizens: Introduction." Politics and Society 42 (3): 287-291.

Pogge, Thomas. 2002. World Poverty and Human Rights: Cosmopolitan Responsibilities and Reforms. Cambridge: Polity Press.

Pogge, Thomas. 1989. Realising Rawls. Ithaca: Cornell University Press.

Quiroz Becerra, M Victoria. 2014. “Performing Belonging in Public Space: Mexican 
Migrants in New York City." Politics \& Society 42 (3): 331-357.

Radoilska, Lubomira. 2014. "Immigration, Interpersonal Trust and National Culture." Critical Review of International Social and Political Philosophy 17(1): 111-128.

Rawls, John. 1971. A Theory of Justice. Oxford: Oxford University Press.

Rigby, Joe and Raphael Schlembach. 2013. "Impossible Protest: Noborders in Calais." Citizenship Studies 17 (2): 157-172.

Sassen, Saskia. 1999. Guests and Aliens. New York: The New Press.

Shachar, Ayelet. 2009. The Birthright Lottery: Citizenship and Global Inequality, Cambridge, MA: Harvard University Press.

Shoukri, Arafat Madi. 2011. Refugee Status in Islam: Concepts of Proteciton in Islamic Tradition and International Law. I.B. Taurus, London.

Sigona, Nando. 2015. "Campzenship: Reimagining the Camp as a Social and Political Space." Citizenship Studies. 19 (1): 1-15.

Smith, Rogers M. 2014. "National obligations and noncitizens: special rights, human rights, and immigration." Politics \& Society 42(3): 381-398.

Soysal, Yasemin. 1994. Limits of Citizenship: Migrants and Postnational Membership in Europe. Chicago: University of Chicago Press.

Tamir, Yael. 1993. Liberal Nationalism. Princeton: Princeton University Press.

Tonkiss, Katherine. Forthcoming. "Experiencing Transnationalism at Home: Open Borders and the Everyday Narratives of Non-Migrants." Politics.

Tonkiss, Katherine. 2013. Migration and Identity in a Post-National World, Basingstoke: Palgrave Macmillan.

Turner, Bryan S. 2001. "The Erosion of Citizenship." The British Journal of Sociology 52 (2): 189-209.

Walzer, Michael. 1983. Spheres of Justice. New York: Basic Books.

Weissbrodt, David. 2009. The Human Rights of Non-citizens. Oxford: Oxford University Press.

Yuval-Davis, Nira. 2007. "Intersectionality, Citizenship and Contemporary Politics of Belonging." Critical Review of International Social and Political Philosophy 10 (4): 561574.

'We are grateful to Peter Nyers for helpful comments on a draft of this paper as well as ongoing support in the production of this special issue; to all of the anonymous reviewers who also assisted us greatly in this process, 
and to the authors of the papers featured in the special issue for their insightful and original contributions to this project.

i" "denizen, n. and adj.". OED Online. December 2014. Oxford University Press.

http://www.oed.com/view/Entry/49985?rskey=VTvOqo\&result=1 (accessed February 20, 2015). 